\title{
Societal entrepreneurs in the health sector: crossing the frontiers
}

\author{
Malin Tillmar \\ Linköping University Post Print
}

Tweet

N.B.: When citing this work, cite the original article.

Original Publication:

Malin Tillmar, Societal entrepreneurs in the health sector: crossing the frontiers, 2009, Social Enterprise Journal, (5), 3, 282-298.

http://dx.doi.org/10.1108/17508610911004340

Copyright: Emerald

http://www.emeraldinsight.com/

Postprint available at: Linköping University Electronic Press

http://urn.kb.se/resolve?urn=urn:nbn:se:liu:diva-100978 


\title{
Societal entrepreneurs in the Health Sector: Crossing the frontiers ${ }^{1}$
}

\author{
Malin Tillmar, Ph. D. Assoc. Prof. \\ Malin.tillmar@liu.se \\ Linköpings Universitet \\ S-581 83 LINKÖPING \\ Sweden
}

\begin{abstract}
This paper explores societal entrepreneurship in the turbulent health-care sector in a changing welfare state, Sweden. By means of two cases, strategies and organizational solutions are highlighted and discussed, as are the long-term preconditions for constructive entrepreneurship in this growing industry. Both entrepreneurs prove to be frontier crossing combiners in several dimensions; (1) they unite ideological commitment with economically sound businesses, (2) they (manage to) bring together their medical professions and complementary methods of treatment, (3) they combine bridge building with challenge(s) and (4) they reconcile part time entrepreneurship with employment. With regard to the long-term preconditions it is concluded that these two entrepreneurial processes have traits of both not only opportunity-exploitation but also of selfexploitation.
\end{abstract}

\section{Introduction: Societal entrepreneurship in a turbulent sector}

It is my contention that mainstream entrepreneurship research still focuses on the private forprofit sector and mainstream social entrepreneurship research still focuses on the private nonprofit sector. Obviously in the latter research field, there is a 'need to move beyond not-forprofit research' (Battle Anderson and Dees 2006, 155). In previous studies of institutional entrepreneurs in the public sector (Sundin and Tillmar 2008a), and SMEs in the care industry (Tillmar 2004) I have encountered many entrepreneurs who could be characterized as social. Schumpeter (1934/1994) argued that entrepreneurship can exist in all kinds of organizations, and that includes entrepreneurship based on a social intention. Consequently, I define social entrepreneurship as 'innovative, social value creating activity that can occur within or across the nonprofit, business, or government sectors' (Austin et al. 2006, 2). By societal entrepreneurship I mean social entrepreneurship driven by the intention of creating value not only 'here and now' but in a broader scope of time and space.

In this paper, I take particular interest in exploring social entrepreneurship occurring across sectoral boarders. This interest is nothing new, but has been shared by pioneers in the social and community entrepreneurship field, such as Johannisson (2005; Johannisson and Nilsson 1989). In this paper, such entrepreneurship will be explored through two individuals whose ambition is to work to promote better health and well-being by complementing local authority care and schoolbook medicine: Yoga teacher and physiotherapist, Ulrika Berglind, and Midwife, Water Aerobics Instructor and Masseuse, Åsa Österberg. Both of these social entrepreneurs extend and challenge current approaches. Their ways of thinking and the strategies and organisatorial solutions that they apply are discussed.

The case studies have been undertaken in the Swedish welfare state in 2008. At this point in time and place, there are great hopes for increased entrepreneurship in the nursing

\footnotetext{
${ }^{1}$ A previous and Swedish version of this paper has been published in the Swedish book 'Samhällets entreprenörer', published by the Swedish foundation for knowledge and competence development, KK-stiftelsen (Gawell, Johannisson and Lundqvist 2009).
} 
and healthcare sector as a result of changes in the public sector. The reforms are currently along the New Public Management lines (Hood 1991), with competition, outsourcing and voucher systems in the service sector as main components (Forsell 2000). Research results about the effects on entrepreneurship are contradictory, however. The entrepreneurs that I have studied to date, have met with decreased demand from the purchasing organisations and a tougher price competition from large companies (Tillmar 2004; Sundin and Tillmar 2008b). On the 'demand side' of entrepreneurship, this turbulence and crisis of the welfare states gives social entrepreneurship an extra dimension, as noted by Nicholls (2006). An urgent question that is discussed here is that of the long-term conditions for social entrepreneurship and the possibilities for social entrepreneurs to create durable organisatorial platforms to allow them to realise their ideas. I find it particularly important to study what is happening in the healthcare sector, which is under strong pressure to change and which is encountering increased demand.

While the conditions for SMEs in the public markets are contestable and subject to both research and vivid political debate, small businesses in that part of the health sector which has a complementary orientation seem to be a growing phenomenon. In this subsector there is another tradition of privately paying customers. The use of complementary and integrative medicine (for example massage and acupuncture) is increasing in the western world and is particularly common in the Scandinavian countries, according to a study made in 2003 (Hanssen et al. 2005). In the Stockholm region, almost 50\% state that they have at some time made use of / used complementary or alternative medicine, most commonly, massage. According to a survey recently carried out in a number of local authorities in Östergötland, (a county in the southern part of Sweden) belief in the future is strong among so-called healthdriven companies ${ }^{2}$ and more than $90 \%$ (of the 270 who have answered the survey) plan to expand (their business).

Empirically oriented questions about the businesses studied that I explore in this paper are: How do the entrepreneurs see combining 'health-driven' and profit-driven enterprises? What mindset and strategies guide their enterprises? What organisatorial solutions are used?

The paper begins below with the background and a description of methodology. As one of the main objectives is explorative, Ulrika's and Åsa's entrepreneurial ventures are then described. This is then followed by a discussion which compares them and which also ties in with earlier work on entrepreneurship and social entrepreneurship. Finally, I reflect over the long-term conditions for social entrepreneurship in this sector.

In mainstream entrepreneurship research, the term 'window of opportunity' or 'strategic window' (cf. Wickham 2006) is often mentioned. The entrepreneur is seen to be a person who discovers an opportunity and (then) acts to exploit it - and goes about exploiting it - often in a market. From this perspective, entrepreneurship is to do with exploiting possibilities, and exploitation is considered to be something positive. In working life research, the term exploitation can have negative connotations, for example, the exploitation of colleagues /workers. As having a private business/running your own business ${ }^{3}$ is a form of labour market behaviour (Hård et al. 2007), the term self-exploitation is also relevant for our understanding

\footnotetext{
${ }^{2}$ Defined in the report as 'Companies that seem to work to improve health and that have a pronounced health or care profile in their business description' (Bilder av hälsodrivet företagande 2008). Sports companies and clubs are not included in the survey.

${ }^{3}$ Just like intrapreneurship
} 
of enterprise and entrepreneurship ${ }^{4}$. Towards the end of the paper, I reflect upon the relationship between exploiting opportunities and self-exploitation for these social entrepreneurs.

\section{Methodology}

There are many examples of social entrepreneurship in a business form in the fields of health, nursing and healthcare which have met with opposition. In an earlier study into the conditions for small companies within nursing and healthcare, hinders prevailed over opportunities (Tillmar 2004). The selection strategy used in this study has therefore been to choose two cases which, when the study began, in my capacity as both a researcher and member of society, I considered to be working well. In this way, I have also wanted to illustrate the possibilities. If the cases still prove to be successful on closer study, the question of why they have been successful arises. What rationale, strategies and organisational solutions have been applied?

The cases described in this paper are built on interviews with the entrepreneurs in question. I have previously participated in courses in water aerobics and yoga respectively, with these entrepreneurs and the businesses and the entrepreneurs behind them had started to fascinate me. ${ }^{5}$

I met midwife Åsa Österberg for the first time in the spring of 2003 when I was expecting my first child and since then, I have followed her destiny and adventures. In the spring of $2006 \mathrm{I}$ once again participated in her water aerobics classes and that spring it happened that we had quite long, informal chats about the way the business was developing. It was not until the spring of 2008, however, that any formal, directed interviews were carried out. It was during 2004 that I first came into contact with the yoga teacher, Ulrika Berglind. Once a week, since the autumn of 2006, I have been participating in her yoga class. This is how I found out that Ulrika is also a physiotherapist and that she is employed at Hälsouniversitetet, (the School of Medicine). Gradually, through participating in the activities, and perhaps especially through social conversations at the end of the yoga sessions, I came to realise that the business is run for reasons other than economic. I had not previously spoken so much with Ulrika about the business and being an entrepreneur. We therefore needed sit and talk on two occasions during the spring of 2008 for me to reach a satisfactory understanding of her way of thinking and working.

\section{The Institute of Yoga, Life Force}

The Institute of Yoga, Life Force, is run by yoga instructor, Ulrika Berglind, who is also a physiotherapist and works as a junior lecturer in Linköping School of Medicine ${ }^{6}$. After completing her training as a physiotherapist, Ulrika spent two and a half years in India where she learned to meditate and tried a variety of body therapies before she finally found yoga. She is trained in the Kundalini tradition in yoga both in Sweden and internationally. The driving force to start the Yoga Institute came from the desire to share this form of yoga and its effects, which she was able to experience during her years in India, with others. 'To do this, I was forced to start my own business':

\footnotetext{
${ }^{4}$ As an example of work-life studies discussing this issue I refer to Thörnquist (2006). With regard to the relation between self-employment and health/stress, I refer to for example Jamal (1997) or Parslow et al. (2004).

${ }^{5}$ Both were positive to taking part. In order to avoid misunderstanding, both entrepreneurs have also read and commented on the case descriptions in special meetings. (or do you mean individual meetings?)

${ }^{6}$ The website in swedish is available at http://www.yogakraft.se/om_livskraft.htm
} 
The premises in which Yoga-institutet Livkraft is located are decorated in light colours and the work was done by Ulrika herself in different stages between 2003 and 2005 with the help of some friends. It was an investment which involved going into debt and thus, incurring risk. Ulrika was prepared to give it a go and explains,' I don't think so far ahead. I just do things. Things just happen.' However, she did think the start through in so far as she 'made a softly softly start to the business', in other words, the yoga institute started in parallel with the gradual renovations so that she could see that there was enough interest. There has been. The yoga premises are almost full for both the early and the late session every weekday.

With a business economics perspective as a point of departure, I think that Ulrika probably doesn't need to have two jobs and therefore ask her about the part-time enterprise. The yoga instructor explains,'I don't want to get into a position where I am dependent on getting customers. I want to be able to do this as a service too.' To market the business offensively is nothing which interests Ulrika. 'I offer yoga and a place to do yoga - for those who want-and I offer the number of sessions a week that there is interest for. If there is a decrease in interest I'll cut down or finish when the time comes. That way, you can't lose.' The basic idea is that the people who go to yoga make an active choice to go to yoga - and that the yoga instructor does not contribute to creating a need.

However, it is important that the business has economically sound returns, partly because of the debts incurred to start up the Institute and partly to pay for goods and services, that is to say that giving and taking are a part of the philosophy of Kundalini yoga. 'If you get yoga, you must also give. You can see it as away of exchanging energy.' Any eventual surplus is re-invested into the business. Last year, Ulrika bought a gong - a special percussion instrument for deep relaxation. She still makes regular trips to India to develop further in yoga and has been trained in the art of Ayurveda medicine and Ayurveda yoga massage.

Her social entrepreneurship is revealed in a variety of ways, amongst others through the service that participants get in the form of products at favourable prices. Relaxation music, yogi-tea and yoga mats among other things, are sold at favourable prices at the Yoga Institute, Life Craft. 'If the fact that it is a little cheaper here can make people happy, then it feels good. I offer it as a service to those who want it, the things are here, but I don't want to advertise either the products or the massage.'

We talk about the fact that various gyms have started with yoga and I ask, again wearing the hat of a business economist, if competition has become tougher. The answer is 'No, there are no competitors. It is good if they start too. The people who are meant to come to Yoga Institute, Life Craft- they find their way here eventually.' Recently the yoga instructor recorded a yoga session on CD to make it easier for people to do yoga at home. This was also done on the initiative and request of the participants and Ulrika sees it as a service. On the back of the CD you can read: 'The profit from the sales of this CD will go to a children's home in India.'

As yoga is not a treatment method that is offered by the local authorities, a local authority agreement is not an option. However, some doctors have started to prescribe yoga as 'physical activity on prescription' to some patients who have completed their medical treatment. This is a relatively new idea within the local authority. A non-profit sports organisation has a contract with the local authority to organise this and follow it up. Ulrika, and her partner who is a yoga teacher in the neighbouring community, have been trained at the sports-organisation to be able to take participants who have asked for yoga as their 
physical activity on prescription. So far, there have not been many however, and only a few people have been in touch.

Ulrika's will to be a social entrepreneur seems to come from a desire to share her yoga. She could not, and still can not do this fully within the framework of the local authorities or her position at the Medical School. However, the yoga instructor is convinced that this will be possible in the future, and says 'I want to be part of it too. To build bridges. And to convey knowledge to both worlds.' The bridge building is easier said than done. The yoga instructor says that there is still a good deal of opposition within a broad spectrum of the trades and professions that think they might have something to lose from the expansion of the CAM industry (Complementary Alternative Medicine).

Even if Ulrika makes a clear distinction between her role as a university lecturer on the Physiotherapy Programme and her role as a yoga instructor, there is no doubt that in both these roles she has use of her double competence. One example is that within the framework of her employment at the medical school, she has been in charge of a 7.5 credit course in Complementary, Alternative Integrative Medicine. As a yoga instructor, it is more the exception than the rule that the participants ask her questions about general worries. Naturally, Ulrika often answers these using both her competence as a physiotherapist and her knowledge of Ayurveda and yoga. Even in her role as yoga instructor, Ulrika is a qualified, authorised physiotherapist, which means that she is very careful about what she says and promises. 'I am authorised 24 hours a day and therefore speak from evidence based methods.' Ulrika consciously limits what goes on in the Yoga Institute's premises to just yoga. Despite the possibilities to arranging some other form of alternative medicine, such as free breathing or liberating dance in the Yoga premises has never been an option. She does not want to confuse the participants or create any questions around the business and its focus.

\section{Freja, Midwifery Clinic}

Midwife, Åsa Österberg, started the midwifery clinic, Freja Inc. in September 2006 together with four midwife colleagues ${ }^{7}$. Since Åsa started to work at the Women's Clinic as a 16-yearold, she has kept noticing room for improvement in maternity welfare. Åsa thought that there was 'too little room by far for the woman and her individual needs'. The importance of exercise and movement during pregnancy was given no room and neither was the need to talk about the worries that pregnancy means or thoughts about the approaching birth. That the future fathers also felt the need to talk was also ignored under the auspices of local authority health care, she claimed. The same applied to women who were frightened of giving birth or who wanted to have the baby at home, because they were afraid of hospitals, for example. The Midwives wanted to offer pregnant women and their families all this. They considered that this was important to get the future families off to a good start.

However, it has been difficult for the midwives to get their ideas accepted within the framework of the local authority for a variety of reasons. Determined Åsa Österberg explains how the establishment of what today is a midwife clinic in a company form has been a long process. She started about eight years ago and managed to realise some, but far from all her ideas within the framework of the local authority. Water aerobics for pregnant women, which was one of Åsa's hobby horses, was one of the ideas that it was difficult to realise within the local authority framework. It was possible to start this outside the local authority with private, paying clients, however, and this is what Åsa did. Since then, she has been employed by the

\footnotetext{
${ }^{7}$ For readers interested the Swedish website is available at http://www.frejabarnmorskemottagning.se/
} 
Women's Clinic part time and run the company part-time and in both roles, her point of departure has been that of a midwife. In connection with the water aerobics, she took the opportunity to offer tea and coffee afterwards to let the women talk about their pregnancies, the birth and the time after. After the gymnastics, she offered mother-child meditation and relaxation exercises in preparation for the birth. The business grew and became popular among pregnant women and Åsa got several like-minded midwives to join her.

Many other midwives working for the local authority began to recommend 'their' pregnant patients to go to water gymnastics, and confirmed the opinion that those who did this were often stronger before the birth and recovered faster, both physically and mentally. In this way, they were a lesser burden on the health services. As is usually the case with changes brought about by entrepreneurial work, this has not been uncontroversial. The midwives have had discussions which at times have been tough but fruitful with local authority politicians. When they talked with the higher echelons (of the local authority) however, they met with opposition. This opposition has not stopped the Freja midwives however. Instead, they have found other ways to realise their ideas. Today, Freja Midwife clinic offers a number of services that the county council cannot afford and does not want to get involved in. Both massage and water aerobics are examples of this. The midwives' rights to leave, like their possibilities to run 'a competing business' are among the things that have been questioned, despite the fact that they can point out many examples where doctors and other professionals do the same thing without it being considered problematic. That spare time occupations are questioned in the case of a midwife but not when it is a doctor, for example, is something that these entrepreneurs find very strange. The Freja midwives themselves say that they do not compete, but just provide a complement.

In September 2006 Freja Midwife Clinic Inc. with five shareholding midwives, opened. For Åsa, the initiator of the project, it was important that they all contributed the same and took the same responsibility. She did not at all want to put in more herself and be the boss. The midwives try to run the company democratically, to wait for each other, until everyone feels that they are ready to take the next step in developing the company and to share out the strategic work among themselves at regular meetings. Different people are responsible for following up different contacts with local authority staff, politicians and potential business partners, for example.

At the present (2008), apart from water aerobics and childbirth classes, the company offers classes for second and third-time mothers, supportive discussions, tactile massage, acupuncture, yoga for pregnant women, coffee meetings for future mothers and new mothers and theme evenings.

Today, the business receives no public financing. The midwives have been in contact with the ruling alliance regime in the county council who have shown themselves positive to some sort of purchasing for maternity care in the region, which would mean that some private operator would get a contract with the county council and thereby receive public financing for certain services. The vision that Åsa and her colleagues share is to be able to give maternity care 'their way', preferably with an agreement with the county council so that they could reach those women who cannot afford to pay themselves. The 30 minutes per visit to the midwife that the county council offer is not enough, Åsa thinks. Freja will offer 40 minutes, of which about 15 will be used for tactile massage. Åsa explains: 'In the stressed, high tempo society in which we are living today, it is really important for women to have a chance to land, to be in their bodies and just be pregnant.' 
The encounter with the future mothers and even fathers is what is central for Freja's midwives. 'This is the philosophy upon which we base our work', says Åsa giving me a sheet of paper with a quotation from Kirkegaard that says:

\begin{abstract}
'When one really wants to succeed in getting a person to a specific goal, I must first find that person where he or she is and start just there. A person who cannot do this deceives him or herself when he thinks that he can help others. It is true that to help someone, I must understand more than what he or she does, but most important is to understand what he or she understands. If I cannot do that, it does not matter that I can do more and know more.'
\end{abstract}

Continuity and to see the family as a whole are the key words for Freja. Families should have the same midwife during the pregnancy, if possible at the birth and in the time after. Asa is strongly convinced about this. If the company does not get a contract with the county council, she is considering expanding the business as a private clinic where the couple as to pay for their maternity care themselves. However, she feels torn about this as it means that the services would perhaps not be available to people with a low income. 'But then we've asked around a bit and found that they have bought a pram for 10,000 , so .... '. What is worse is to be classed as a competitor and thus not be allowed to work on the labour ward. This is important not only from the perspective of competence development, but also for Åsa and the others as individuals. 'To be with a woman and a man when they have a baby is so fantastic ... it is almost like being addicted to cocaine, .... You just can't stop.'

The right to have another job on-the-side is a dilemma for the Freja midwives and realising their ideas through a company rather than through the county council can be seen as a disadvantage. Another disadvantage is economic. The business in its newly extended 'Freja form' is not yet breaking even. But despite her great enthusiasm, Åsa is trying to be patient and give the business a little time. It isn't always easy for the five Freja midwives, and at their meetings it can often be noticed that one of them is feeling a bit down or is experiencing a sense of hopelessness. The fact that Freja is being run as a private enterprise has however been important for them in relation to their midwife colleagues within the county council. The resources that the county council, and by extension that the Women's Clinic has, are limited. As the Freja midwives have put their own capital into the business and premises, there is less risk that their colleagues feel that they are making use of the county council's resources. At the same time, Åsa stresses that there is nothing 'strange' about Freja's business. The point of departure is the licence to practice the profession of midwife. She is therefore not happy to see the business as 'alternative'. Instead, the Freja midwives are very particular to build upon solid training in their respective fields of competence, proven experience and taking part in research studies to be able to show and test the effects of their treatment methods scientifically.

That the water aerobics- and later on, Freja Midwife clinic - have enriched the Women's Clinic and vice versa is clear. Åsa recommends women to have large 'Pilates balls' as support for moving their bodies during the early stages of childbirth. As far back as 2003, I found out that Åsa had bought two such balls and donated them to the labour ward. That the county council would pay for these was something that Åsa considered too unlikely to even bother asking. Her midwife colleagues laughed and joked with Åsa about her ideas. When more and more women who had been to the water aerobics used the balls and even bought their own and took them up to the labour ward when it was time to give birth, more and more of Åsa's colleagues caught on to the idea. In 2007, even the maternity care provided by the 
county council started to include water aerobics for pregnant women. This shows in Freja's cashbox and at the same time, Asa thinks that it is 'cool' that the county council is adopting these ideas.

Today, the Freja midwives have a very successful cooperation with the labour ward and the Women's Clinic. For example, when Åsa comes to the labour ward with a woman that she is going to assist under Freja's auspices, she is also happy to help with other things on the ward when time allows without this costing the county council anything extra. According to Åsa Österberg, the Freja midwives feel that they have support from the politicians. What has been more difficult over the years has been to convince the bosses higher up in the organisation. It is there that misunderstandings can more easily come up as the people there do not know the actual work, as well as the immediate bosses do, says Åsa. The possible contract with the county council will be taken up in 2009 .

\section{Social entrepreneurs as frontier-crossing combiners}

Put simply, entrepreneurship is seen here as seeing or creating the opportunity to realise an idea, and then doing just that. The definition is broad, but is close to the one proposed by Schumpeter (1934/1994), the classical entrepreneurship researcher. The idea does not have to be a product which had never previously existed, but can build on new ways to combine existing goods or services in another context. To be a frontier-crossing combiner is thus common among entrepreneurs. The frontier crossing is to do with dealing with paradoxes, something that has previously been discussed by Johannisson (2005).

The entrepreneurs described here are frontier-crossing combiners in (at least) four ways. They combine:

(1) 'improving the world' with running an economically viable business

(2) their professions with complementary medicine

(3) bridge building with challenging

(4) running a business with being employed.

The first point is an important reason why I consider that the activities carried out by Ulrika and Åsa as social and societal entrepreneurship. It is also why they are cases discussed in this paper on social entrepreneurship across sectoral boarders. The second point accounts for the content of their visions, which are connected not only to helping the individual for the moment, but in the long run, even perhaps will result in better service for society. The last two points involve the strategies the two entrepreneurs employ to realise their ideas. These four frontier- crossing combinations are discussed below.

\section{'Improving the world' AND running a business.}

To my way of thinking, entrepreneurship is not limited to starting new companies. Despite this, this paper is about entrepreneurs who have realised their ideas through a business. What distinguishes them is that the business has not been an aim in itself but a means to reach the societal goal that can be given the collective name 'constructive promotion of the health and well-being of members of the society.'

The rules of play for social and societal entrepreneurship have increasingly become a matter of discussion both in Sweden and internationally. The terms social and societal entrepreneurship are closely related. They have been imported from both Anglo-American and Continental European traditions and are used in different ways. The cases presented here fall within Palmås $(2008,246)$ definition of societal entrepreneurship as 'the ability to change 
the world by running an economically viable company' ${ }^{8}$. In other words, they 'combine the passion of a social mission with an image of business-like discipline, innovation and determination' (Dees 1998, 1). So Freja Midwife Clinic and the Yoga Institute, Life Force are hybrids in that they are financed by the actual business itself but have explicit societal goals. They show that entrepreneurship and social entrepreneurship are a part of their daily activities. ${ }^{9}$ Both cases exemplify the unclear borders/frontiers between profit driven and nonprofit driven companies. ${ }^{10}$ The difference between societal entrepreneurship and commercial entrepreneurship is for them a question of level rather than of character. The formal association form is not always a reliable indication of what type of business and/or entrepreneurship lies behind it.

What is common to both the yoga teacher and the midwife is a commitment for the people in the society, or rather, the region, where they operate. Local commitment is given a central role in Johannisson's (2005) discussions on community entrepreneurship. In the cases which are presented here, the commitment is about access for local and regional citizens, to the kinds of health promoting services that are offered. The motivation is not far from needs driven motivation in the sense used by Gawell (2007) in her thesis. Societal entrepreneurs see it as necessary that the people who live in the area have access to their services. Neither Ulrika nor Åsa are the first in Sweden with their businesses. They work actively to maintain their networks and cooperative relations with like-minded people in the Stockholm region as well as in other places. However, as far as I know, they are the only people to offer these services in the region of Östergötland, Sweden. What is entrepreneurial about them is partly that they introduce an already existing idea into a new context in order to change the current way of doing things, something that in the discourse around institutional entrepreneurship is called 'borrowing strategies' (Lowndes 2005).

\section{Caring Professions AND Complementary Methods}

To work at the same time both within traditional medicine and complementary medicine is a further frontier breaking dimension that applies to both these entrepreneurs. The midwife is the one who most clearly takes her profession into the business. She really practises her profession in her capacity as a midwife and incorporates methods such as massage, meditation and motion into that role. In the role of yoga instructor, the physiotherapist derives a great advantage from her professional competence and in her teaching role in the physiotherapy programme, she benefits from her knowledge of yoga and Ayurvedisk medicine. The combination of (their) two worlds is central to the very idea behind both these cases of social entrepreneurship, as I understand it. This is where their socially useful motivation, or what other researchers call 'the ethical fibre' (Catford 1998) is to be found.

\footnotetext{
${ }^{8}$ Palmås means that the development of the company form has resulted in societal goals hampering the company, and for example makes it more difficult to finance the business. The new, British inspired association form, 'company with limited profit sharing' is discussed and evaluated by Palmås (2008) who claims that in Sweden, there is a need for special so-called social banks for these companies.

${ }^{9}$ Compare for example, the discussions in the special number of the Journal of Entrepreneurship and Regional Development volume 16:3 2004, for example by Steyaert and Katz, and by Rehn and Taalas.

${ }^{10}$ As Gawell (2007) discusses, this border is being challenged from several directions, both by the companies' social responsibility organisations (the debate on Corporate Social Responsibility) and by the non-profit-making 'fundraising ventures'.

${ }^{11}$ That the formal association form can be confusing has also been discussed by Lindkvist (2008) in connection with his studies of personal cooperatives. Views vary however among the different schools of thought within the 'entrepreneurship field'. Bacq and Janssen (2008) divide the American tradition into two schools, where the socalled 'social enterprise school' focuses on non-profit making organisations while the so-called 'social innovation school' is closer to the perspective which I take in this paper.
} 
As Baumol pointed out, entrepreneurship is not by definition something positive. It can be productive, but also unproductive or even destructive. Society's task is to shape the rules of the game that channel entrepreneurship into becoming something productive, Baumol (1996) claims. The word productive can lead us to think along the wrong lines in this context, where it is a question of services which promote health. I prefer to call the entrepreneurship discussed above 'constructive'. In the case of the midwife, this distinction between constructive and productive (in a narrow technical sense) can be seen as one reason for the clashes with county council logic. According to the midwife, in certain cases, productivity is measured by how many complications the clinic has managed to deal with. Thus working constructively to prevent complications is not always considered by everyone to be productive. The question as to how the entrepreneurs deal with these contrasting logics leads us to the next frontier-breaking combinatorial role.

\section{Bridge-building AND challenging}

To build bridges and to make it possible for school-medicine and complementary medicine to learn from each other, and to incorporate new, constructive models into the health care provided by the county council, are explicit goals for both of them. In this way, I can see them as challengers or at any rate, as people who stretch the limits. I do not consider either the midwife or the yoga instructor to be revolutionaries. I see them rather as reformers. As I see it, their strategies have been, that building on a thorough education and training in their fields, to carefully and on a small scale, introduce treatment methods which they consider to be healthier and more constructive than those currently employed. Gradually, ideas from their entrepreneurial development work have spread and enriched the work of the public domain. In the midwife's case, the integration of her philosophy into the heath care provided by the county council has happened through the consumers/patients, almost as an unintentional consequence of her work. The pregnant women in the town who went to her water gymnastics classes and for example wanted to use a pilates ball when they gave birth increased in number. The midwife tells us how her colleagues and bosses were sceptical at first, but had to accept the situation when more and more women with labour pains came to the hospital carrying their own balls. In this way, the methods for doing things were done gradually changed due to the patience of the entrepreneurs. ${ }^{12}$

\section{Social Entrepreneurship through running a business AND employment}

Common to both the yoga instructor and the midwife is that they practise their professions by being employees of the state and the county council while at the same time, they offer health promoting services through their business activities. They are thus part-time business people and belong to the category known as combiners, (that is to say, they combine running a business with employment) and want this to continue. ${ }^{13}$ Their reasons for wanting to stay part-time business people are partly different.

The midwife considers it necessary to keep her role as a county council employee and work part of the time on the labour ward. In this way, she keeps in touch with what is central to the work and the development that is taking place there. Just as important is it to keep close contact with bringing new lives and families into the world, which is the basis of a midwife's choice of profession and is something which is very important to them as people.

\footnotetext{
${ }^{12}$ For further discussion of the patience that is demanded and the opposition that entrepreneurs can meet when they strive to change the established order of things, for example in the health care sector; see the article mentioned above, 'A Nurse and a Civil Servant Changing Institutions', Sundin and Tillmar 2008a.

${ }^{13}$ Different categories of part-time business and combiners have been discussed by Sundin, 2006.
} 
A survey of part-time businesses made by Sundin (2006), shows that within the sector social and personal services, this is a common organisational form. The yoga instructor explains that it can be difficult for many people to be able to earn a good salary in the field of complementary health care. For her, the choice of running a business part-time is rather a very conscious decision to refrain from full-time business. She does not want to be dependent on having a certain number of participants but wants to be able to continue to run her business 'as a service'. This socially oriented motive for running a business is central to Ulrika's entrepreneurship and not giving up her job is a conscious strategy to enable her to be able to maintain this motive.

The fact that the yoga instructor and the midwife run their businesses part-time does not mean that their societal entrepreneurship is a part-time project. Both of these entrepreneurs are working to build bridges between their respective activities from both ends, so to say. Both are working for change and development for the good of the people and their patients even within the framework of their respective positions of employment. In this way, running a business part-time fulfils yet another purpose; it facilitates institutional entrepreneurship in the public sector.

\section{Conclusions}

In this section I would like to summarise the discussions above by referring to the ways of thinking and the strategies that govern running a business as well as the possibilities to combine health-driven and profit-driven businesses. What are the long-term conditions for social entrepreneurship $\mathrm{n}$ this sector and what is the relationship between exploiting opportunities and self-exploitation?

The ways of thinking and the strategies that influence these entrepreneurs are both similar and different. The desire to combine running their own business with an almost ideological societal ambition is common to both, just like their combiner-strategy. By this latter, I mean that they strive to combine employment where their respective professions are practised with running their own businesses. Their motives for this are slightly different. The midwife explains it as a matter of competence development and something that can best be expressed as 'being where life is'. For the yoga instructor, it is a question of not becoming dependent on the business and on having a certain number of customers. Common to both entrepreneurs is their desire to also contribute to development and learning within the county council heath care service and the School of Medicine. Both Ulrika and Åsa have been, and still are involved in research projects whose goals are to investigate the effects of their respective treatment methods with scientific methods used within medicine? To distance themselves from methods of treatment which are too untried and untested and which can be seen as unserious, is something that I interpret is important to both of them.

The possibility to combine health-driven - in the sense of a passion for health care and profit-driven businesses differs between the two cases with regard to both approach and practical reality. The nature of the two businesses is different in that the county council supplies maternity care but not yoga. The Yoga Institute is open to everyone in the region. Thus, its customer base is wider than Freja's, whose potential customer base is for natural reasons, more restricted. Whereas the yoga instructor's philosophy is that the treatment you pay for yourself probably gives the beat results, the midwife is more torn about the matter of couples having to pay out of their own pockets. My interpretation however, is that in both of 
the cases presented here, economic motives are clearly subordinate to other driving forces. ${ }^{14}$ Common to both businesses too, is that they are situated in professions and branches with a female hallmark, where according to previous research, the potential to make a profit is often lower than in businesses with a male hallmark (Sundin 2002; Nutek 2003). ${ }^{15}$ As has been pointed out in other contexts, there is a risk that opportunities in these businesses are lower. The gender system's repercussions on running a business can eventually lead to a risk that women's social entrepreneurship initiatives, for example in the heath sector, become characterised more by self-exploitation than by exploiting opportunities (for health-effects on self employment, see Dolinsky and Caputo 2003).

The relationship between exploiting opportunities and exploiting yourself are so closely dependent upon the entrepreneurs' own experience. At the outset, I chose the cases of Ulrika and Åsa because I considered their companies to be working well and I also wanted to describe the opportunities. There are obviously opportunities, but the descriptions show that there are also traits of self-exploitation. A great deal of the midwife's energy has been spent on discussions with people from the authorities and with senior management. It is not impossible that their relatively subordinate professions have played a role in this. ${ }^{16}$ This latter has not been an issue for the yoga instructor as her business is of a different character, but she has still spent a lot more time and energy on the business than she would have needed to earn a living. There is a very large grey area between what the entrepreneurs consider to be work and what they consider to be meaningful spare time; something that is so often the case with entrepreneurs. Both Ulrika and Åsa have found 'their thing' and invested their time in what also gives them something in return - even if it has not always been in the form of money. As is shown in the descriptions above, the returns in the form of energy (to use the Yoga Instructor's term) have so far been a little to lean, especially in one of the cases. The future will show if this constructive societal entrepreneurship will get enough resources to be sustainable in the long-term.

Finally, let us conclude that this paper has contributed to social and societal entrepreneurship studies by exploring strategies and organizational solutions by entrepreneurs acting across sectoral boarders in their ventures. The paper has also in a sense contributed to studies in public and institutional entrepreneurship, as the cases used are also applicable to such definitions. In particular, entrepreneurship in the era of NPM has been illuminated from a new angle. Furthermore, many empirical examples in the literature on social entrepreneurship are "great men", such as the Nobel prize winner Muhammad Yunus from the micro-finance institution Grameen Bank in Bangladesh. Apart from micro-finance, Nicholls (2006) refers to global movements within fair trade or renewable energy. As noted also by others, there is a need to focus on the everydayness of entrepreneurship (Steyaert and Katz 2004) and on micro-level initiatives (Parkinson and Howorth 2008). In this sense too, the cases presented here are contributions.

\section{Further research}

The focus on social and societal entrepreneurship extends the possibilities of making visible arenas of entrepreneurship which have not previously received enough light (cf. Berglund and

\footnotetext{
${ }^{14}$ This in itself is nothing unique, but is commoner than one would perhaps believe, according to earlier studies on entrepreneurship. See for example Johannisson, 2005.

${ }^{15}$ In this paper I abstain from taking up a more general discussion on gender perspectives and content myself with stating that these exist.

${ }^{16}$ For a deeper discussion on professions and gender logic, refer to Sahlin-Andersson, 1994 and Johansson, 1998.
} 
Johansson 2008). Both entrepreneurship in the public sector and entrepreneurship in branches which bear a typically female stamp belong to these arenas (Lundström and Sundin 2008; Sundin and Tillmar 2008a). Even if empirical studies of these arenas are increasing in number, there is still a great deal to be done. The conditions for societal entrepreneurship in different organisational forms and in different sectors - that is to say within the public sector, the private sector and within non-profit organisations - are something that I consider raise an important and over-riding question. What are the conditions for social entrepreneurship within the framework of organisations in different sectors and different professions? How does the acceptance of part-time jobs affect different professions? At the moment, - as was stated at the beginning - radical changes are taking place throughout the welfare sector in Sweden. The cases presented here highlight the fact that there is no clear line between what is a profitdriven and what is a non-profit-driven enterprise. The line between what is public and what is private is even more vague (Christensen and Laegreid 2005). This paper can be regarded as a contribution to research into the role of social and societal entrepreneurship in a changing welfare state. But, much more research into this is needed.

\section{Acknowlegements}

The author wish to thank the Swedish Council for Working Life and Social Research, FAS, the Swedish Government Agency for Innovation Systems, Vinnova and the Knowledge Foundation, KKstiftelsen, for funding which has enabled this research.

\section{References:}

Austin, J., H. Stevenson and J. Wei-Skillern.2006. Social and commercial entrepreneurship: Same, different, or both? Entrepreneurship Theory and Practice 31, no. 1: 1-22.

Bacq, Sophie and Frank Janssen. 2008. From social entrepreneurship as a practice to a legitimate Field of research: Literature review and classification. Paper presented at the European Summer University Conference on Entrepreneurship, August, $22^{\text {nd }}-26^{\text {th }}$, Bodö, Norway.

Battle Anderson, Beth and J. Gregory Dees. 2006. Rhetoric, reality and research: Building a solid foundation for the practice of social entrepreneurship. In Social entrepreneurship: New models of sustainable social change, ed. Alex Nicholls. Oxford: Oxford University Press.

Baumol, W.J. 1996. Entrepreneurship: Productive, unproductive, and destructive. Journal of business Venturing 11, no. 1: 3-22.

Berglund, Karin and Anders W. Johansson, eds. 2008. Arenor för entreprenörskap. Örebro: Forum för Småföretagsforskning, 2008:4.

Bilder av hälsodrivet företagande, Maj 2008, NuLink (Linköpings Kommun), Jamntillväxt, Finspångs Kommun, Motala kommun och Norrköpings Kommun.

Catford, J. 1998. Social entrepreneurs are vital for health promotion: But they need supportive environments too. Health Promotion International 13, no. 2: 95-97.

Christensen, T., et al. 2005. Organisationsteori för offentlig sektor. Malmö: Liber.

Dees, J. Gregory. 1998. The Meaning of social entrepreneurship. Kauffman foundation: 1-5 
Dolinsky, A.L. and R.K. Caputo. 2003. Health and female self-employment. Journal of Small Business Management 41, no. 3: 233-241.

Forssell, Anders. 2000. Reform theory meets new public management. In New public management: The transformation of ideas and practice, ed. Tom Christensen and Per Lægreid. Aldershot: Ashgate.

Gawell, Malin. 2007. Activist entrepreneurship attac'ing norms and articulating disclosive stories. PhD dissertation. Stockholm: School of Business, Stockholm University.

Gawell, Malin, Bengt Johannisson and Mats Lundqvist, eds. 2009. Samhällets entreprenörer: En forskarantologi om samhällsentreprenörskap. Stockholm: KK-stiftelsen.

Hanssen, B., S. Grimsgaard, L. Launso, V. Fonnebo, T. Falkenberg and N.KR. Rasmussen. 2005. Use of complementary and alternative medicine in the Scandinavian countries. Scandinavian Journal of Primary Health Care 23, no. 1: 57-62.

Hood, C. 1991. A public management for all seasons. Public Administration 69, no. Spring: 3-19.

Hård, Ursula, Elisabeth Sundin and Malin Tillmar. 2007. Kvinnors företagande: Arbetsmarknadsbeteende och organisatorisk lösning, Arbetsliv i omvandling, 2007:4. Stockholm: Arbetslivsinstitutet.

Jamal, M. 1997. Job stress, satisfaction and mental health: An empirical examination of selfemployed and non-self-employed Canadians. Journal of Small Business Management 35, no. 4: 48-57.

Johannisson, Bengt. 2005. Entreprenörskapets väsen. Lund: Studentlitteratur.

Johannisson, B. and A. Nilsson. 1989. Community entrepreneurs: Networking for local development. Entrepreneurship \& Regional Development 1, no. 1: 3-19.

Johansson, U. 1998. Transformation of gendered work: Dualistic stereotypes and paradoxical reality. Gender, Work \& Organization 5, no.1: 43-58.

Lindkvist, L. 2008. Tänder tillsammans: När landsting inför personalkooperativ som vårdorganisation. Kommunal Ekonomi och Politik 12, no. 1: 35-56.

Lowndes, V. 2005. Something old, something new, something borrowed... Policy Studies 26, no. 3/4: 291-309.

Lundström, Anders and Elisabeth Sundin, eds. 2008. Perspektiv på omvandling och förnyelse i offentlig sektor. Örebro: FSF.

Nicholls, Alex, ed. 2006. Social entrepreneurship: New models of sustainable social change. Oxford: Oxford University Press.

NUTEK. 2003. Kvinnors företagande: Format av samhället, Företagens villkor och verklighet 2002, Anna Bunger, rapport B 2003:7. Stockholm: Nutek. 
Palmås, Karl. 2008. Socialt entreprenörskap: Ny sektor eller rebranding av ideellt arbete? In Perspektiv på förnyelse och entreprenörskap $i$ offentlig verksamhet, ed. Anders Lundström and Elisabeth Sundin. Örebro: FSF.

Parkinson, C. and C. Howorth. 2008. The language of social entrepreneurs. Entrepreneurship and Regional Development 20, no. 3: 285-309.

Parslow, R.A., A.F. Jorm, H. Christensen, B. Rodgers, L. Strazdins and R.M. D’Souza. 2004. The associations between work stress and mental health: A comparison of organizationally employed and self-employed workers. Work \& Stress 18, no. 3: 231244.

Rehn, A and S. Taalas. 2004. Znakomstva i svyazi [Acquaintances and connections]: Blat, the Soviet Union, and mundane entrepreneurship. Entrepreneurship and Regional Development 16, no. 3: 235-250.

Sahlin-Andersson, Kerstin. 1994. Varför låter sig organisationer omvandlas? In Organisationsexperiment $i$ kommuner och landsting, ed. Bengt Jacobsson. Stockholm: Nerenius \& Santérus förlag.

Schumpeter, Joseph. 1934/1994. The theory of economic development. In Om skapande förstörelse och entreprenörskap, ed. Richard Swedberg, Stockhom: City University Press, Ratioklassiker.

Steyaert, C. and J. Katz. 2004. Reclaiming the space of entrepreneurship in society: Geographical, discursive and social dimensions. Entrepreneurship and Regional Development 16, no. 3: 179-196.

Sundin, E. 2002. Företagandets manliga prägel. In Företagerskan: Om kvinnor och entreprenörskap, ed. Carin Holmquist and Elisabeth Sundin. Stockholm: SNS

Sundin, E. 2006. Deltidsföretagande. In Deltidsarbetslöshet som lösning eller problem för arbetsgivare och företagare, ed. Gunilla Rapp and Elisabeth Sundin. Arbetsliv i omvandling, 2006:5. Stockholm: Arbetslivsinstitutet.

Sundin, E. and M. Tillmar. 2008a. A nurse and a civil servant changing institutions: Entrepreneurial processes in public sector organizations. Scandinavian Journal of Management - special issue on 'Recreating/Recontextualising entrepreneurship', guest editors Daniel Hjorth, Campbell Jones, and Bill Gartner, 24, no. 2: 113-124.

Sundin, Elisabeth and Malin Tillmar. 2008b. Kvinnors entreprenörskap i och genom offentlig sektor: Möjlighetsexploatering eller självexploatering? In Perspektiv på förnyelse och entreprenörskap i offentlig verksamhet, ed. Anders Lundström and Elisabeth Sundin. Örebro: FSF.

Tillmar, Malin. 2004. Är det möjligt? Om villkor för småföretag $i$ vård- och omsorgssektorn. Nutek 2004:4. Stockholm: Nutek. 
Thörnquist, Annette. 2006. Anställda blir företagare - en fråga för facket: Exempel med nutidsrelevans från den skandinaviska granitindustrin under mellankrigstiden. In När anställda blir företagare: Studier om företagande $i$ ett strukruromvandlings- och arbetsmarknadsperspektiv, ed. Elisabeth Sundin and Annette Thörnquist. Arbetsliv i omvandling, 2006:17. Stockholm: Arbetslivsinstitutet.

Wickham, Philip A. 2006. Strategic entrepreneurship (fourth edition). Harlow: Financial Times Prentice Hall.

http://www.yogakraft.se/om_livskraft.htm. Accessed 2009-03-24.

http://www.frejabarnmorskemottagning.se/. Accessed 2009-03-24. 